\title{
Correction to: Differential production and secretion of potentially toxigenic extracellular proteins from hypervirulent Aeromonas hydrophila under biofilm and planktonic culture
}

\author{
Priscilla C. Barger ${ }^{1,2^{*}}$, Mark R. Liles ${ }^{2}$, Benjamin H. Beck ${ }^{3}$ and Joseph C. Newton ${ }^{1 *}$
}

Correction to: BMC Microbiol 21, 8 (2021)

https://doi.org/10.1186/s12866-020-02065-2

Following publication of the original article [1], we were notified of a mistake in author affiliation 1, which was introduced after the proofs were approved.

Originally published affiliation: Department of Biological Sciences, College of Sciences and Mathematics, Auburn University, Auburn, AL, USA.

Corrected affiliation: Department of Pathobiology, College of Veterinary Medicine, Auburn University, Auburn, AL, USA.

The original article has been corrected.

The publisher apologizes for any inconvenience.

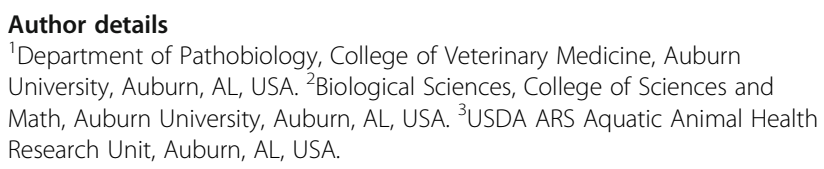

Published online: 22 January 2021

\section{Reference}

1. Barger, et al. Differential production and secretion of potentially toxigenic

extracellular proteins from hypervirulent Aeromonas hydrophila under biofilm and planktonic culture. BMC Microbiol. 2020;21:8. https://doi.org/10. 1186/s12866-020-02065-2.

The original article can be found online at https://doi.org/10.1186/s12866020-02065-2

* Correspondence: bargepc@auburn.edu; newtojc@auburn.edu

'Department of Pathobiology, College of Veterinary Medicine, Auburn University, Auburn, AL, USA

Full list of author information is available at the end of the article

C C The Author(s). 2021 Open Access This article is licensed under a Creative Commons Attribution 4.0 International License, which permits use, sharing, adaptation, distribution and reproduction in any medium or format, as long as you give appropriate credit to the original author(s) and the source, provide a link to the Creative Commons licence, and indicate if changes were made. The images or other third party material in this article are included in the article's Creative Commons licence, unless indicated otherwise in a credit line to the material. If material is not included in the article's Creative Commons licence and your intended use is not permitted by statutory regulation or exceeds the permitted use, you will need to obtain permission directly from the copyright holder. To view a copy of this licence, visit http://creativecommons.org/licenses/by/4.0/. The Creative Commons Public Domain Dedication waiver (http://creativecommons.org/publicdomain/zero/1.0/) applies to the data made available in this article, unless otherwise stated in a credit line to the data. 